\title{
Contribution of Training Variations to Improving Basic Skills in Playing Futsal
}

\author{
Nopi Hariadi ${ }^{1 *}$, Abdul Haris Jaelani ${ }^{2}$ \\ ${ }^{1}$ Department of Physical Education Health and Recreation, Universitas Hamzanwadi, Selong, Indonesia \\ ${ }^{2}$ MI NW Selong, Selong, Indonesia \\ *Corresponding author. Email: 060614.harijadi@gmail.com
}

\begin{abstract}
This study aimed to determine whether there was contribute variations in training on improving basic skills in playing Futsal in MAN 1 Lotim Futsal team in 2019. This research used an experimental method of observation and action tests as data collection techniques. The subjects in this study were Futsal players who were members of the MAN 1 LOTIM Futsal team in 2019, comprising 20 people. The design of the study used one group pretest posttest design, which means there was a pretest before being treated. I analyzed data using the t-test as a research hypothesis test. The results of data analysis showed that $t_{\text {Count }}>t_{\text {table }}$ as 2.956 $>2.093$ so H0 reject and Ha accept. So we can conclude it that there contribute training variations on improving basic skills in playing Futsal of MAN 1 LOTIM team in 2019.
\end{abstract}

Keywords: Variations of training, basic skills, futsal

\section{INTRODUCTION}

Line with its development, Futsal is now a priority on coaching in extracurricular activities. (Hamzah \& Hadiana, 2018; Khairandi, 2018; Mustari, 2017; Setyadi, 2017) Futsal is one sport branch included in the big ball game. Futsal, developed into one of the alternative football games, looked at the efficiency of the use of smaller land or playing fields. Therefore, Futsal considers as a game able to give the same sensation of play as gained by the player while playing football. Playing Futsal has regard as a lifestyle in big cities. All circles can play it among teenagers and students. It is supported by a variety of Futsal field facilities that mushed in every city and make this sport one of the most played sports by the community. As with football, Futsal can create a game that ends with competition and competition.

But the fundamental thing of playing Futsal is aiming to form a team game with a slick play strategy, combined with various techniques of each individual who plays for victory. The game's quality is determined by mastery of basic techniques such as passing, controlling, dribbling, and shooting to the goal. In Futsal play, players can better master game techniques such as ball mastery, attack combinations, and survive. (Kurniawan \& Mylsidayu, 2017). For children, teenagers, and students, Futsal will be very helpful for them to develop the instinct and skill of playing football.
Through the observation results, the failures cause by the skills of basic techniques of the players, in this case, the MAN 1 Lotim Futsal team is lacking so it is necessary to improve. According to the researchers observation and also information from Futsal Cocontractor and trainer in MAN 1 Lotim that, seen when passing the ball to a teammate are often less directional so we took the mastery of the ball over by the opposing team. In terms of the smaller field, so in Futsal play very demanding cooperation between players through the accurate operand. But the ability to play is the weakness of each team. The main factor underlying the weakness is the lack of basic engineering skills by each player in the MAN 1 Lotim Futsal team.

Based on the explanation above, the researcher tries to raise a problem by analyzing the variables with a study titled Variation of Exercise variations on the improvement of the basic skills of playing Futsal in MAN 1 Lotim Futsal team year 2019.

\section{METHOD}

In this study, the research subject is Futsal player who joined in the MAN 1 LOTIM Futsal team in 2019 which amounted to 20 people and taken in total. Sampling techniques about this study are the total sampling, which is a sampling technique in which the number of samples is equal to the population (Sari \& Dewi, 2019). The reason for taking the total sampling as according to The number of population less than 100 the entire population made a sample of all research. 
In this study, the data collection techniques used are observation techniques and test deeds. The observation technique is done to find and collect the data of the players in the MAN 1 Lotim Futsal team as the subject of the study. The action test technique is done to measure the basic skill mastery level of Futsal play.

\section{RESULT AND DISCUSSION}

From the results of the analysis of the research data got the T-Calculate value of 2.956, the number of subjects studied 20 people with degrees of freedom $(\mathrm{N}-$ 1) $20-1=19$ with a significant level of $5 \%$ because the data used is data on the observation results in the field where Researchers realized that it is very difficult to keep the research condition so, then the $t_{\text {table }}$ value shows the number 2.093 , this means the value $t_{\text {Count }}$ greater than $t_{\text {table }}$ or $2.956>2.093$. The zero hypothesis rejects and an alternative hypothesis is acceptable.

The form of variation of exercise is done so that training or learning activities are not boring to athletes or learners and increase motivation for athletes to follow the training activities. The usual exercises are in the form of changes in implementing exercises to improve performing athletes, such as a dribbling exercise while zig-zag through the stakes,(Grant, 2019). The implementation by the zig-zag through the stakes that have proved and arranged in both directions, back to the starting point. The goal is to do both ways within 30 seconds.

Objectives and benefits of exercise variation (Narlan, Juniar, \& Millah, 2017)

1. To raise and increase students' attention to the relevant aspects of teaching.

2. To provide opportunities for development, talents want to know and investigate the students about new things.

3. Teachers give students or athletes the opportunity to get away to receive the lessons it please them with

A professional Futsal player must master the basic techniques in a Futsal game. (Do Nascimento, Gomes, Mota, Aparecida, \& de Melo, 2016; Hutomo, Kristiyanto, \& Purnama, 2019; Vieira et al., 2016). The basic technique is an important element in the Futsal game, without the mastery of basic technique, the game cannot play. (Bompa \& Buzzichelli, 2018).

\section{CONCLUSION}

From the results of the data analysis and the hypothesis testing above, it can conclude that "there is a variation the exercise on the basic skill improvement in playing Futsal in the MAN 1 Lotim Futsal team in 2019" which means the results prove That the variety of basic techniques exercises in Futsal play contributes to improvement of the basic skills of playing Futsal on the MAN 1 Lotim Futsal team that later had a positive impact on the players while facing Game in the field.

\section{ACKNOWLEDGMENTS}

A study cannot run without the involve include many parties which always helps in the process from the beginning to the end of the research. On this occasion the researcher would like to thank all the research personnel who have spent time, energy and thoughts that are material or moral so that this research can be complete on time, hoping the results continue to be a beneficial development of sports, for Futsal sports, both for coaches Futsal athletes, trainers and athletes.

Thank the researchers also to the trainers and research subjects (Athlete) MAN 1 Lotim who have been willing to become research subjects to be give treatments in the form of variations for training to see the ability of athletes to variations the basic skills of playing Futsal.

\section{REFERENCES}

Bompa, T. O., \& Buzzichelli, C. (2018). Periodization-: theory and methodology of training. Retrieved from books.google.com

Do Nascimento, M. G. B., Gomes, S. A., Mota, M. R., Aparecida, R., \& de Melo, G. F. (2016). Psychological profiles of gender and personality traces of Brazilian professional athletes of futsal, and their influence on physiological parameters. Psychology Research and Behavior Management, 9, 41.

Grant, T. R. (2019). Sports training device. Google Patents.

Hamzah, B., \& Hadiana, O. (2018). Pengaruh Penggunaan Model Problem Based Learning Terhadap Keterampilan Passing Dalam Permainan Futsal. JUARA: Jurnal Olahraga, 3(1), 1-7.

Hutomo, A. S., Kristiyanto, A., \& Purnama, S. K. (2019). The Use of Video Media in Improving Futsal Basic Techniques Skills of Male Students of Futsal Hobbyist. International Journal of Multicultural and Multireligious Understanding, 6(4), 140-143.

Khairandi, N. (2018). Aplikasi Pembelajaran Teknik Dasar Futsal Menggunakan Augmented Reality Berbasis Android. Skripsi.

Kurniawan, F., \& Mylsidayu, A. (2017). Development of Futsal Basic Technique Training Model for Beginner Based on Playing Methods. JIPESJournal of Indonesian Physical Education And Sport, 3(1), 26-32.

Mustari, M. R. (2017). Pengaruh Koordinasi mata kaki kelincahan dan percaya diri terhadap kemampuan dribbling pada permaianan futsal BP2IP Barombong Makassar. 
Narlan, A., Juniar, D. T., \& Millah, H. (2017). Pengembangan Instrumen Keterampilan Olahraga Futsal. Jurnal Siliwangi Seri Pendidikan, 3(2), 62.

Sari, P. P., \& Dewi, A. S. (2019). Pengaruh Komitmen Organisasional Dan Profesional Terhadap Kepuasan Kerja Dengan Motivasi Sebagai Variabel Intervening Pada Pegawai UPT Dinas Kesehatan Puskesmas Air Bangis Pasaman Barat. Retrieved December 27, 2019, from osf.io

Setyadi, N. G. (2017). Tingkat Pengetahuan Siswa Kelas V Di Sekolah Dasar Negeri Ngleri 1 Gunungkidul Tentang Peraturan Permainan Futsal. PGSD Penjaskes, (1).

Vieira, L. H. P., Doğramaci, S. N., Barbieri, R. A., Milioni, F., Moura, F. A., Andrade, V. L. de, ... Santiago, P. R. P. (2016). Preliminary results on organization on the court, physical and technical performance of Brazilian professional futsal players: comparison between friendly pre-season and official match. Motriz: Revista de Educação Física, 22(2), 80-92. 